\title{
THE SYSTEM OF EDUCATION IN THE REPUBLIC OF KAZAKHSTAN: PAST, PRESENT AND FUTURE
}

\author{
Zhamilya T. Makhambetova, Akmaral S. Magauova \\ Al-Farabi Kazakh National University, Almaty, Kazakhstan
}

\begin{abstract}
It is provided a panorama of comparative studies related to the education system in the Republic of Kazakhstan to compare the advantages and disadvantages of education systems in the article. The authors considered in detail the structure and current situation of the education system in the Republic of Kazakhstan, the legal framework of the education system, languages of instruction at schools, additional education, the system of higher education in the country, training of persons with SEN (special educational needs) as well as Kazakhstan's education system in the context of pandemic. Currently, the republic needs the development of distance learning, the training of highly qualified personnel in the education system of the Republic of Kazakhstan.
\end{abstract}

Keywords: context of pandemic, distance learning, higher education, preschool education, Republic of Kazakhstan, secondary education, system of education

\section{Introduction}

It is a fact that the state of the education system of the countries is of great importance in modern society. Knowledge and understanding of the state of education systems in different countries makes it possible to understand the advantages and disadvantages in their own countries, as well as the keys to reform and improvement.

Reviewing the recent literature, the problems of the system of education still remain relevant. Bulekbayev, Zhakyanova (2017) conducted a comparative analysis of education systems in Kazakhstan and Russia. The researchers consistently analyzed the result of the reforms that have been carried out over the years of independence. The education system is an area where the final product is not immediately visible. In this regard, it was emphasized that it is necessary to deliberately and purposefully develop education in the country; this is an area that does not accept hasty decisions. Researcher Kontsipko (2012) presented a comparative analysis of master's degree training on the example of a multi-level education system in the Republic of Kazakhstan and the Russian Federation on the example of the Novosibirsk State University of Economics and Management. The advantages and disadvantages of the transition to credit technology of education in the framework of the Bologna process were considered. Kirdasinova, et al. (2016) explored the current state of the education system in the republic of Kazakhstan and its growth perspectives. The researchers provided evidence for the urgent need in innovative instruments to develop the educational system and described the processes of demand formation for highly qualified specialists. Kuznetsova and Maslennikova (2015) carried out a content analysis of data from a number of specialized education sites in the studied countries, such as: USA, UK, Finland and Singapore. The content features of various education systems were identified and considered, taking into account the practice-oriented approach. Researchers identified both positive and negative aspects of the considered education systems. 
The article of Vakhabova (2020) is devoted to the prospects of development and disadvantages of distance learning in the Republic of Kazakhstan. It expressed the opinions of foreign experts about online education. The results of a survey of ordinary Kazakh students on the necessary measures in education in the era of the coronavirus pandemic were presented. According to the researcher, self-isolation is the path to self-education and self-reflection.

Comparative analysis is a method of comparing two or more objects of research (phenomena, ideas, objects, results, etc.). As a result of such analysis, the advantages and disadvantages of the objects are being compared (Kolessova, 2018). In this case educational systems are compared. Next, we will focus in more detail on the current situation of the education system of the Republic of Kazakhstan.

\section{The System of Education in the Republic of Kazakhstan}

\section{The Legal Framework of the Education System of Kazakhstan}

Over 30 years of independence of the Republic of Kazakhstan the system of education has undergone many changes. The legal framework of the education system of Kazakhstan is determined by the Constitution of the Republic of Kazakhstan, the Law of the Republic of Kazakhstan "On Education" and other regulatory and legislative acts. Article 30 of the Constitution of the Republic of Kazakhstan establishes the right of citizens of Kazakhstan to compulsory secondary education and the possibility of obtaining higher education. Changes in the direction of reforms can also be traced on the basis of an analysis of three generations of laws on education of the Republic of Kazakhstan.

\section{Table 1}

Three generations of Laws on Education of the Republic of Kazakhstan

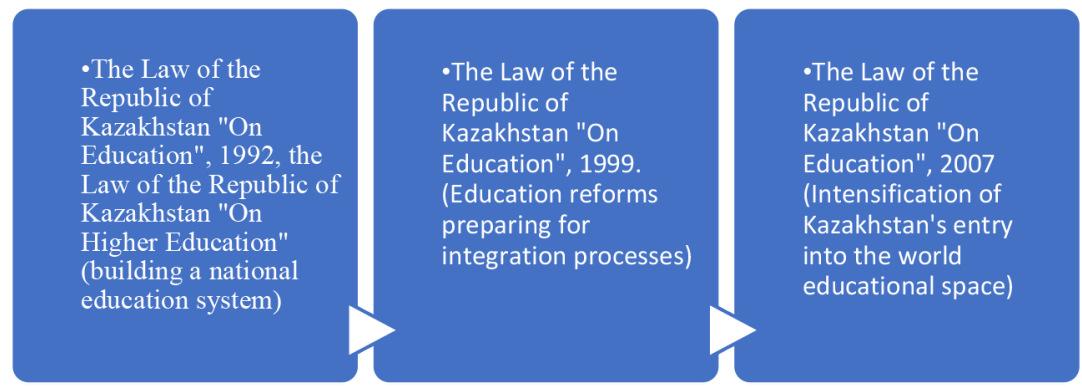

Note: From "Fundamentals of higher school pedagogy" by A. K. Mynbaeva 2008, p.16).

Reforms of the education system are being actively carried out in Kazakhstan. Since 2007, the previously existing system of postgraduate and doctoral studies has been eliminated, the PhD doctoral program was being introduced. Since the same year, the magistracy has been brought to the level of postgraduate education. Now and further in 2010 it will be transformed according to the legislation on education of the Republic 
of Kazakhstan in 2007 and the State Program for the Development of Education of the Republic of Kazakhstan. Changes have been made to the structure in accordance with the projects of ongoing reforms.

The Government of the country has taken seriously the issue of obtaining preschool education. Private and public investments have led to a rapid increase in the number of institutions for preschool education. Approaches to upbringing have also undergone significant changes. People realized that childhood is not only a preparation for life at school, but also a separate important stage in the formation of a person's personality. The main thing was the development of the child's independence and self-sufficiency. The learning process for preschool children began to be built on the basis of a game with a gradual complication of the task and growing out of entertainment into creativity. This approach allows to maintain the child's interest in obtaining new knowledge and to form a model of human relations. There are the centers of Maria Montessori Methodology and Mental Arithmetic in the Republic. There are 10,719 preschool organizations operating in the republic, of which 6,269 are state-owned (there are 539,020 children in them), 4,450 private units (there are 367,780 children in them). There are 788,388 children in 6,843 kindergartens, 118,412 children in 3,876 mini-centers (Committee of Preschool and Secondary Education of the Ministry of Education and Science of the Republic of Kazakhstan, 2021).

\section{Figure 1}

\section{LP "The Center of Montessori Alma-Ata"}
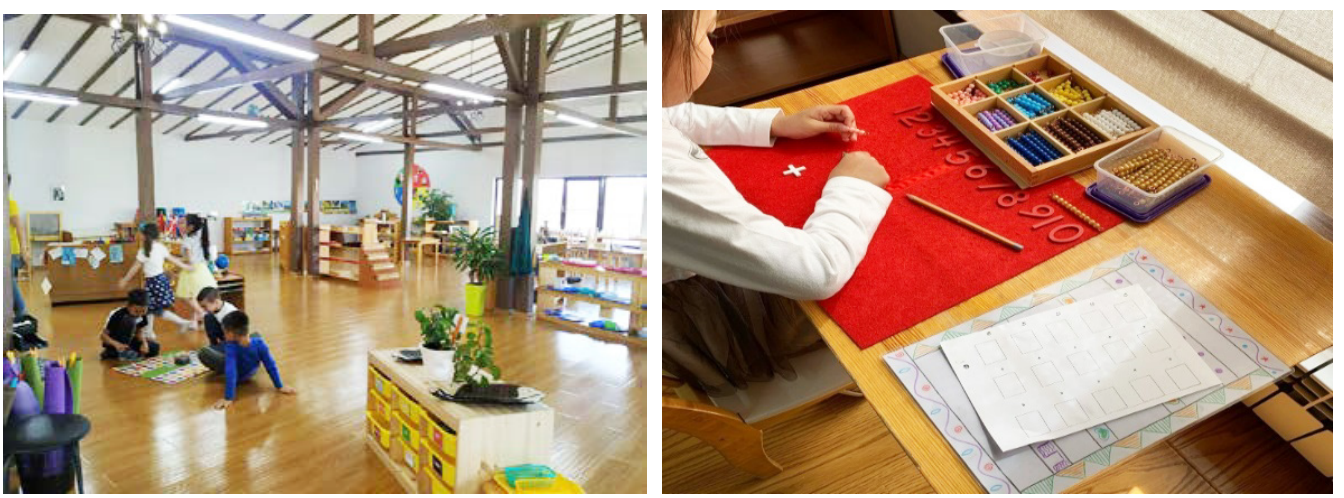

Secondary education in Kazakhstan implies an eleven-year system of schooling. It is divided into several stages:

primary (grade 1-4);

basic (grade 5-9);

senior (grade 10-11(12))

(Mynbaeva, 2008; The education system in Kazakhstan - trends and features of development (n.d.)).

The new requirements imply the need to develop critical thinking and the ability to analyze the situation.

Introduction of criteria-based assessment to determine student performance. This system helps to assess the personal achievements of each high school student and 
determine his strengths, identifying areas that need to be worked out further. The effectiveness of a child's understanding of educational materials is determined by conducting a control test after studying each new theme. The result is expressed as a percentage and shows how the student coped with the task. The assessment for the quarter is formed on the basis of all control works. Data on how the child learns is recorded in an electronic diary, available for online viewing by parents. Learning loads are gradually decreasing and the amount of time spent on homework is decreasing. Afive-day school week is being introduced in schools and the number of school hours is being reduced (The education system in Kazakhstan - trends and features of development (n.d.)).

Languages of instruction. During an interview conducted on June 7, 2021, Minister of Education and Science stated that there are approximately $75 \%$ of schools in Kazakhstan with Kazakh as the language of instruction, the remaining 25\% with Russian (Bazhkenova, 2021) An interesting innovation was the introduction of the study of some subjects (chemistry, physics, biology) in English. This option is still possible only for high school students after the relevant decision of the board of Trustees. Gradually, where the training was conducted in Russian, they begin to increase some of the subjects in the Kazakh language.

The situation with textbooks has changed: new electronic versions can be used from any gadgets.

In 2008, at the initiative of the First President of the Republic of Kazakhstan, Leader of the Nation Nursultan Nazarbayev, a project was launched to create Intellectual schools. One of the key projects contributing to the modernization of the secondary education system of the Republic of Kazakhstan is "The Nazarbayev Intellectual Schools" project. The Nazarbayev Intellectual Schools (NIS) is a network of schools for exceptional students of age 5 to 18 throughout Kazakhstan. Previously, each school focused primarily on a specific set of subjects: either physical sciences and mathematics, or chemical and biological sciences, as well as foreign languages. Instruction is trilingual: in Kazakh, Russian and English. The program was initially set up with the assistance of faculty members from the University of Pennsylvania Graduate School of Education. Subsequently, NIS partnered with the University of Cambridge Faculty of Education; Netherlands on the testing and measurement; and Johns Hopkins University on working with talented youth ("Nazarbayev Intellectual Schools," 2021).

Kazakh-Turkish lyceums are a network of schools for especially gifted children under the leadership of the International Public Foundation "KATEV" in Kazakhstan. About 4,000 students of KTL (BIL) became winners and prize-winners of international intellectual Olympiads. Lyceums provide education in four languages: Kazakh, Russian, Turkish and English. Lyceums are divided into male, female and joint. The first "Bilim Innovation Lyceum" in Kazakhstan appeared in 1992 in the city of Alma-Ata ("KazakhTurkish lyceums," 2021).

Additional education Today, there are 1,272 additional education organizations in the country. Among them 1,160 are public, 112 are private. At the end of last year, President Kassym-Jomart Tokayev signed a law that will allow children to attend sports clubs and creative circles for free of charge. This law was developed on the initiative of the Commissioner for Children's Rights Aruzhan Sain (Clubs and sections in Kazakhstan: what innovations are expected this year? 2021). 


\section{The System of Higher Education in Kazakhstan}

Young people in the country receive higher education (bachelor's degree, specialist) and postgraduate education (master's degree, residency, doctoral studies). Applicants enter public and private universities based on the results of the unified national test - UNT. Unified National Test is one of the forms of qualifying exams for admission to organizations of higher and (or) postgraduate education (National Testing Center, 2021). Among all the Commonwealth of Independent States (CIS) countries, Kazakhstan has carried out the most radical changes in the system of higher education. The first stage (1991-1994). Formation of the legislative and regulatory framework of higher education. The main objectives of this stage were the creation of a network of higher education institutions and the renewal of higher education specialties in order to ensure the independence of the republic in training personnel, meeting the needs of the market economy and regions. The measures taken during this period found legislative consolidation to the Law of the Republic of Kazakhstan - On Higher Education (1993). In 1994, the State Standard of Higher Education of the Republic of Kazakhstan (Conceptual principles) was approved, which for the first time defined the introduction of a multi-level structure of higher education in the country, academic degrees of bachelors and masters. The second stage (1995-1998). Modernization of the higher education system, updating its content. This stage is characterized by a conceptual definition of the development of the higher education system, which is reflected in the Concept of State Policy in the field of education, approved by the National Council for State Policy under the President of the Republic of Kazakhstan on August 4, 1995, the adoption of new regulatory legal principles regulating the activities of higher education institutions. From 1995 to 1997, the first Kazakh educational standards were adopted in 310 specialties of higher professional education. The third stage (1999-2000). Decentralization of management and financing of education, expansion of academic freedom of educational organizations. At this stage, there is a real decentralization of the management system of educational organizations. The principles of admission to higher educational institutions have changed dramatically, the transition to the training of specialists with higher professional education on the basis of a state educational order has been carried out. The fourth stage (beginning of 2001 - present). Strategic development of the higher education system (Mynbaeva, 2008, pp.15-16).

In 2007, the following procedure for obtaining higher education was determined:

1. Bachelor program - Duration of study is determined by the State Compulsory Standard of higher education and must be not less than four years.

The task of the bachelor's degree is to train specialists with a higher professional education and a practical orientation of activity for work in various state and non-state organizations, including in secondary vocational educational institutions in positions corresponding to this qualification.

2. Master's degree is based on Bachelor studies plus a Master program in two areas:

- Scientific-pedagogic education with a duration of two years of study.

- Profile with a duration of a minimum of one year of studies. Those who have passed the final attestation and publicly defended their Master dissertation are awarded the academic degree of Master in the relevant discipline. Persons entering the master's program take CT (comprehensive testing). CT is carried out for persons who have mastered the educational programs of higher education. Admission to the Master's 
program is made on a competitive basis based on the results of comprehensive testing (CT).

- Acceptance of applications for Master's degree in higher education institutions in Kazakhstan is held from June 15 to July 15 of the calendar year.

- Comprehensive testing is carried out from July 20 to August 10.

From the latest news on Master's degree in Kazakhstan 2021:

Admission to master's and doctoral studies will now be held twice a year. This was stated by the Minister of Education and Science A. Aimagambetov. The first Master's degree (CT) exams will be held traditionally in August, and the second will be held in December. Acceptance of documents for the December entrance exams to the magistracy will begin in November. It is planned that this norm will come into force in the current 2021(Kazakhstan has changed the rules for admission to doctoral and master's degrees, 2021).

The profile magistracy provides in-depth professional training. The training is applied in nature and is aimed at developing management skills in all areas of activity. The task of the profile magistracy is to train professional managers. The scientific and pedagogical magistracy provides in-depth scientific and pedagogical training and prepares personnel for the system of higher and postgraduate education, as well as for the scientific sphere. Graduates of the scientific and pedagogical Master's degree can teach at universities.

3. Doctoral studies comprise preparing a Doctor of Philosophy (Ph.D) and doctoral studies in selected disciplines (Doctorantura) upon completion of a Master program. The duration of study is a minimum of three years.

Since 2011, the credit technology of education has been introduced in the higher education system of the Republic of Kazakhstan with the aim of international recognition of national educational programs and ensuring the mobility of students and teaching staff.

\section{College - University System}

In Kazakhstan, a pilot project has been launched since 2019, which allowed graduates of some colleges to continue their studies at universities under new conditions: students are transferred to the university based on the results of the curriculum. This became possible thanks to the unified system of credit-modular training.

\section{Extramural, External (Zaochnoe) or Distance Learning}

Previously, there was extramural, external (zaochnoe) form of study for students of higher education in the Republic of Kazakhstan, but since January 1, 2019, it has been suspended. It is being replaced today by modern distance higher education or a part-time system. Now it is possible to create a flexible schedule: lectures and classes are held on weekends or in the evening.

The second higher education in Kazakhstan is obtained only on a paid basis with an accelerated period of study (2-3 years). On behalf of the president, the allowance of preservice doctors and teachers has been increased - almost twice (Scholarships of pre-service doctors and teachers in Kazakhstan have been doubled, 2021). 
Table 2

Structure of the Education System of the Republic of Kazakhstan according to 2007

\begin{tabular}{|c|c|c|c|c|c|}
\hline \multicolumn{6}{|c|}{ PhD doctoral program } \\
\hline \multicolumn{3}{|c|}{$\begin{array}{l}\text { Master's degree } \\
\text { Scientific and pedagogical, } 2 \text { years of study }\end{array}$} & \multicolumn{3}{|c|}{$\begin{array}{l}\text { Master's degree } \\
\text { Profile, } 1 \text { year of study }\end{array}$} \\
\hline \multicolumn{6}{|c|}{ Reduced terms of study } \\
\hline \multicolumn{2}{|l|}{$\begin{array}{l}\text { Senior level } \\
\text { Grades 10-11 (12) }\end{array}$} & \multicolumn{2}{|c|}{$\begin{array}{l}\text { Primary vocational } \\
\text { education }\end{array}$} & \multicolumn{2}{|c|}{$\begin{array}{l}\text { Secondary vocational } \\
\text { education 3-4 years of study }\end{array}$} \\
\hline $\begin{array}{l}\text { General } \\
\text { education classes }\end{array}$ & $\begin{array}{l}\text { Classes with a } \\
\text { gymnasium bias }\end{array}$ & $\begin{array}{l}\text { Professional } \\
\text { school 2-3 } \\
\text { years of } \\
\text { study }\end{array}$ & $\begin{array}{l}\text { Lyceum } \\
3(4) \text { years of } \\
\text { study }\end{array}$ & $\begin{array}{l}\text { Training } \\
\text { school }\end{array}$ & College \\
\hline \multicolumn{6}{|c|}{ The main stage } \\
\hline $\begin{array}{l}\text { General } \\
\text { education classes }\end{array}$ & \multicolumn{2}{|c|}{ Classes with a gymnasium bias } & \multicolumn{2}{|l|}{ Gymnasium } & Lyceum \\
\hline \multicolumn{6}{|c|}{ 5-9 grades, i.e. 5 years of study } \\
\hline \multicolumn{6}{|c|}{ Pre-school education [1-6 (7)] } \\
\hline
\end{tabular}

Note: From "Fundamentals of higher school pedagogy" by A. K. Mynbaeva 2008, p.14

Al-Farabi Kazakh National University, is a university in Almaty, Kazakhstan. It is one of the country's largest universities. The university is located in Almaty, the largest city in Kazakhstan, previous capital, with a population of more than 2 million people. KazNU is the oldest classical university of the Republic established in 1933. One year after Kazakhstan's 1990 declaration of independence, the name was changed to Al-Farabi Kazakh State University. More than 20,000 students, post-graduates and $\mathrm{PhD}$ students study at KazNU, and there are more than 2500 faculty members working at KazNU, including 400 Doctors of Science, professors and more than 800 candidates of science and associate professors ("AlFarabi Kazakh National University," 2021). Al-Farabi Kaz NU became the first among the universities of Kazakhstan and Central Asia to sign the Great Charter of World Universities on September 16, 2003 (Al-Farabi Kazakh National University has joined the Charter of World Universities, 2003). According to the QS World University Rankings KazNU takes 165th place in the rating of the best universities of the world (Kazakhstani educational institutions were included in the ranking of the best universities in the world, 2020). In 2021, the university was named as one of the Top 500 Universities in the World.

The international scholarship "Bolashak" was established on November 5, 1993 by the Decree of the President of the Republic of Kazakhstan Nursultan Nazarbayev. At the dawn of the independence of the Republic of Kazakhstan, highly qualified personnel were required to carry out further reforms. For the first time in the history of the post-Soviet states, talented young people were given the opportunity to study abroad ("Bolashak," 2021). To obtain it, it is necessary to have a high average score of the certificate, as well as high-level knowledge of Kazakh and foreign languages. The reforms that the educational 
system of Kazakhstan is going through are an objective necessity. They were caused by the dynamics with which science, economics and technology are developing. In the new reality, the requirements for people have become new. They should not just be smart, but creative, have non-standard thinking, be mobile and dynamic, quickly master new technologies. The national economy is developing thanks to human resources. Therefore, the education system in Kazakhstan is gradually being updated in order to raise individuals who are able to make a significant contribution to this process (The system of Education in Kazakhstan in 2021, 2021).

\section{Training of Persons with Special Educational Needs (SEN)}

During the Government meeting chaired by the Prime Minister of the Republic of Kazakhstan A. Mamin on social protection of persons with disabilities, Minister of Education and Science A. Aimagambetov spoke about the creation of conditions for the education of persons with special educational needs. According to A. Aimagambetov, currently 139,887 people in Kazakhstan are persons with SEN. Among them, 3,520 people are studying at higher educational institutions. Among the measures of state support provided to citizens with special educational needs, the Minister named: free meals; the choice of the form of study; students with visual and hearing disabilities - an increased scholarship of $75 \%$ (29,328 tenge); allocation of at least $1 \%$ of the quota for the disabled in the distribution of grants; free places in dormitories. As for the creation of a barrier-free environment, by 2025 it is planned to increase the share of educational institutions prepared for the admission of persons with disabilities to high levels: colleges - $100 \%$ and universities also up to $100 \%$ (MES RK: 139,887 people with special educational needs live in Kazakhstan, 2020).

\section{Kazakhstan's Education System in the Context of a Pandemic}

According to the interview with the Minister of Education of Republic of Kazakhstan A. Aimagambetov, for Kazakhstani schools, the current situation was completely new and unexpected. On a rush basis, it was necessary to prepare materials, programs, shoot video tutorials, develop new teaching rules, assessments, and instructions, conduct training courses for teachers, deploy special Internet platforms for distance learning and conduct explanatory work with the parent community. Taking into account the existing problems and opportunities, after studying international experience, recommendations of UNESCO and the World Bank, it was decided to use several distance learning technologies at once:

- Internet learning;

- training through TV channels and radio;

- regular training in remote villages, as well as sending educational materials via mail in settlements where there are no schools.

Due to the current situation, it was immediately decided to cancel the final exams for grades 9 and 11. The distance format also influenced the building of a new quality of relationships between teachers and parents, showing the importance of close interaction. The situation in colleges and universities was better. Universities have already had some experience in introducing distance learning technologies into the learning process. The materials of mass open online courses (MOOC) were used in the educational process, 
and the universities themselves had previously developed programs for students traveling on academic mobility programs, for students who are unable to study full-time for health reasons. And therefore, since March 16, 2020, 116 civil universities have successfully switched to distance learning at once, although certain problematic issues also existed. The overwhelming number of students went to their parents, but 5,000 Kazakhstani students and 4,000 foreign students stayed in dormitories at the place of study. Accordingly, all the necessary conditions for distance learning have been created in the dormitories. In order to improve the quality of education, republican online seminars were held daily on various aspects of organizing training using distance learning technologies. All universities and colleges have Help Desk, a system that provides technical support to students and teachers. The world is living in a period of a new digital era, said the Minister, and much has been said about this. Different scenarios of development were developed: somewhere quickly, somewhere slowly. But the crisis forced us to find solutions quickly. And in general, the education system managed to withstand the first wave. The pandemic will pass, but now we need to be ready for the emergence of new "black swans", to work in the world of "VUCA" (in conditions of volatility, uncertainty, complexity, and ambiguity of the world) (Kazakhstani's education system in the context of a pandemic. First lessons, 2020). In early October 2020, in Kazakhstan it was conducted a survey on the topic of "Distance education" on the subscriber base of fixed telephone numbers in 14 regions of the republic. 1100 people participated in the ratio of $25 \%$ of men and $75 \%$ of women over 18 years old in the state and Russian languages. $16 \%$ of respondents endorsed online learning and considered it a necessity due to the current situation around the world. $43 \%$ of respondents who did not accept the system, and $38 \%$ of respondents treated it with understanding and expected changes for the better in the Kazakh Internet supply system. According to the survey, the vast majority of residents rated the effectiveness of online learning below average (42\%), and average ( $41 \%)$. In total, only $12 \%$ of respondents highly appreciated the new form of education (Vakhabova, 2020).

The Ministry of Education and Science of the RK has developed a draft concept for the development of education in the Republic of Kazakhstan until 2025 (The concept of education development until 2025 was developed in Kazakhstan, 2021). The implementation of the education development policy is aimed at ensuring accessibility and inclusiveness, improving the quality of education at all levels, developing functional literacy, providing lifelong education, and training personnel that meet both the current needs of the labor market and the needs of the future economy.

The system of continuing education of the Republic of Kazakhstan is developing in line with international educational trends, as well as the national model of education has been formed in the country. Over the past years, the education system has been modernized in the republic. Kazakhstani's education system is characterized by globalization and openness. In the future, it is necessary to improve the education system in the context of globalization, digitalization, as well as distance learning. It is necessary to improve the system of training highly-qualified professionals that meets international educational standards. 


\section{References}

Al-Farabi Kazakh National University (2021, November 18). In Wikipedia. https://en.wikipedia.org/ wiki/Al-Farabi_Kazakh_National_University

Bazhkenova, G. (2021, June 7) Pochemu v kazakhstane russkikh shkol stanovitsya men'she? Otvet ministra [Why are there fewer Russian schools in Kazakhstan? The Minister's response] [Video]. Sputnik. https://ru.sputnik.kz/education/20210607/17266351/kazakhstan-russkieshkoly.html

Bolashak (2021, November 18). In Wikipedia. https://en.wikipedia.org/wiki/Bolashak

Bulekbaev, S. B., Zhakyanova, A.M. (2017). Problems of Reforming the education System in Kazakhstan https://www.semanticscholar.org/paper/Problems-of-Reforming-the-EducationSystem-in-Bulekbaev-Zhakyanova/e929216dbcb792024e62728b7b2db226d96f7eea\#: : text=Bulekbaev\%2C\%20S.B.\%2C\%20\%26\%20Zhakyanova\%2C\%20\%D0\%90.M.\%20 (2017).\%20Problems\%20of\%20Reforming\%20the\%20Education $\% 20$ System $\% 20$ in $\% 20$ Kazakhstan.

Kazakhskii natsionalnyi universitet im. Al-Farabi prisoedinilsya $k$ Khartii universitetov mira [AlFarabi Kazakh National University has joined the Charter of World Universities] (2003, September 22). Caravan, Retrieved from https://www.caravan.kz/news/kazakhskijjnacionalnyjj-universitet-im-alfarabi-prisoedinilsya-k-khartii-universitetov-mira-188996

Kazakhsko-Turetskie litsei [Kazakh-Turkish lyceums] (2021, November 18). In Wikipedia https:// ru.wikipedia.org/wiki/\%D0\%9A\%D0\%B0\%D0\%B7\%D0\%B0\%D1\%85\%D1\%81\%D0\%BA $\% \mathrm{D} 0 \% \mathrm{BE}-\% \mathrm{D} 1 \% 82 \% \mathrm{D} 1 \% 83 \% \mathrm{D} 1 \% 80 \% \mathrm{D} 0 \% \mathrm{~B} 5 \% \mathrm{D} 1 \% 86 \% \mathrm{D} 0 \% \mathrm{BA} \% \mathrm{D} 0 \% \mathrm{~B} 8 \% \mathrm{D} 0 \% \mathrm{~B} 5$ $\% \mathrm{D} 0 \% \mathrm{BB} \% \mathrm{D} 0 \% \mathrm{~B} 8 \% \mathrm{D} 1 \% 86 \% \mathrm{D} 0 \% \mathrm{~B} 5 \% \mathrm{D} 0 \% \mathrm{~B} 8$

Kirdasinova, K. A., Turmakhanbetova, Sh. Sh., Shayakhmetova, Sh. T., Mukhamedzhanova, A. G., \& Nurmukhametov, N. N. (2016). Innovative Development of the Education System in the Republic of Kazakhstan. International Business Management, 10(16), 3449-3460.

Kolessova, A. (2018). Sravnitel'nyi analiz: ponyatie, vidy i primery [Comparative analysis: concept, types and examples] (2018, March 28) Retrieved from https://fb.ru/article/46080/sravnitelnyiyanaliz-passionarnosti-i-poiskovoy-aktivnosti-lichnosti

Komitet doshkol'nogo I srednego obrazovaniya Ministerstva obrazovaniya I nauki Respubliki Kazakhstan [Committee of Preschool and Secondary Education of the Ministry of Education and Science of the Republic of Kazakhstan]. (2021). Doshkol'noe obrazovanie [Preschool Education]. https://www.gov.kz/memleket/entities/kdso/activities/5961?lang=ru

Konseptsiyu razvitiya obrazovaniya do 2025 goda razrabotali v Kazkhstane [The concept of education development until 2025 was developed in Kazakhstan] (2021, October 21) https://news.mail.ru/politics/48438185/?social=fb\&fbclid=IwAR1DxfhDQWL61BB6HR JBx5ZX0WK4AljbP5YpHf6FkP-gPvIIm9HRooepWU

Kontsipko, N. V. (2012). Sravnitel'nyi analiz rossiiskoi i kazakhstanskoi mnogourovnevoi sistemy obrazovaniya [Comparative analysis of the Russian and Kazakh multilevel education system]. Bulletin of Tomsk State University. Economics, 3(19), 159-167.

Kruzhki I sektsii v Kazakhstane: kakie novshestva ozhidayutsya $v$ etom godu? [Clubs and sections in Kazakhstan: what innovations are expected this year?] (2021, January 26). Білімді ел/ Образованная страна, Retrieved from https://bilimdinews.kz/?p=134530

Kuznetsova, O. I., Maslennikova, E. G. (2015). Natsional'nye doktriny i sistema obrazovaniya raznykh stran [National doctrines and education system of different countries]. Personality, Family and Society: Issues of Pedagogy and psychology, 2 (49).

MON RK: v Kazakhstane prozhivayut 139887 chelovek s osobymi obrazovatel'nymi potrebnostyami [MES RK: 139,887 people with special educational needs live in Kazakhstan] (2020, December 2) https://primeminister.kz/ru/nemon-rk-v-kazahstane-prozhivayut-139887chelovek-s-osobymi-obrazovatelnymi-potrebnostyami-211499 от 2.12.2020 
Mynbaeva, A. K. (2008). Osnovy pedagogiki vysshei shkoly [ Fundamentals of higher school pedagogy]. Almaty.

Natsional'nyi Centr Testirovaniya [National Testing Center] https://testcenter.kz/ru/postupayushchimv-vuz/ent/edinoe-natsionalnoe-testirovanie-ent/ (2021, November 18).

Nazarbayev Intellectual Schools (2021, November 18). In Wikipedia https://en.wikipedia.org/wiki/ Nazarbayev_Intellectual_Schools

Sistema obrazovaniya v Kazakhstane - tendentsii I osobennosti razvitiya [The education system in Kazakhstan - trends and features of development] (n.d.) https://nauka.club/pomoshchstudentu/sistema-obrazovaniya-v-kazakhstane.html

Sistema obrazovaniya $v$ Kazakhstane v 2021 godu [The system of Education in Kazakhstan in 2021] (2021, February 11)https://www.nur.kz/family/school/1773601-novaa-sistema-obrazovaniav-kazahstane-2018-2019/

Sistema obrazovaniya Kazakhstana $v$ usloviyakh pandemii. Pervye uroki [Kazakhstani's education system in the context of a pandemic. First lessons] (2020, May 19) https://liter.kz/sistemaobrazovaniya-kazahstana-v-usloviyah-pandemii-pervye-uroki/

Stipendii budush'ikh medikov I pedagogov v Kazakhstane uvelicheny vdvoe [Scholarships of preservice doctors and teachers in Kazakhstan have been doubled] (2021, September 9). $24 \mathrm{Mir}$, Retrieved from https://mir24.tv/news/16474135/stipendii-budushchih-medikov-i-pedagogovv-kazahstane-uvelicheny-vdvoe

Vakhabova, G. I. (2020). Perspektivy razvitiya distancionnogo obucheniya v Kazkhstane [Prospects for the development of distance learning in Kazakhstan]. Pedagogical Science and Practice, 4(30),111-115.

$V$ Kazkhstane izmenili pravila postupleniya $v$ doktorantutu I magistranturu [Kazakhstan has changed the rules for admission to doctoral and master's degrees] https://www.zakon.kz/5081690-vkazahstane-izmenili-pravila.html (2021, November 18)

$V$ reiting luchshikh vuzov mira popali 10 kazakhstanskikh uchebnykh zavedenii [Kazakhstani educational institutions were included in the ranking of the best universities in the world] (2020, June 10). Retrieved from https://www.zakon.kz/5026771-v-reyting-luchshih-vuzovmira-popali-10.html

Received 23 November 2021; Accepted 28 December 2021 
Cite as: Makhambetova, Zh. T., \& Magauova, A. S. (2021). The system of education in the Republic of Kazakhstan: Past, present, and future. Švietimas: politika, vadyba, kokybé / Education Policy, Management and Quality, 13(2), 110121. https://doi.org/10.48127/spvk-epmq/21.13.110

\section{Zhamilya Targynovna Makhambetova}

Senior Lecturer, Department of Pedagogy and Educational Management, Faculty of Philosophy and Political science, Al-Farabi Kazakh National University, Masanchi str., 39/47, 408, Almaty, Kazakhstan.

E-mail: mzhamilya@mail.ru, mzhamilyam@gmail.com

ORCID: https://orcid.org/0000-0001-8458-3749

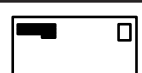

Akmaral Sabitollayevna Magauova

Professor, Doctor of Pedagogical Sciences, Department of Pedagogy and Educational Management, Faculty of Philosophy and Political science, Al-Farabi Kazakh National University, Masanchi str., 39/47, 408, Almaty, Kazakhstan.

E-mail:magauova@mail.ru

ORCID: https://orcid.org/0000-0002-0667-1011 